\title{
FIELD MAPPING IN THE SCORESBY SUND AREA, EAST GREENLAND
}

\author{
Niels Henriksen
}

The five year field mapping programme in the Scoresby Sund area which was begun in 1968 continued during the 1969 season. This season the expedition was based on the 1855 ton polar vessel "Magga Dan", which carried two Bell helicopters and supported three smaller boats; 38 expedition members and $30 \mathrm{crew}$ members participated in the expedition which lasted 63 days. The expedition members included 15 two-man geological parties, of which 7 mapped in the Caledonian crystalline complex north and south of outer Nordvestfjord, two in the crystalline complex in south-western Liverpool Land, one party in Tertiary basalts south-west and south of Hall Bredning; one party made Quaternary geological investigations on eastern Milne Land and western Jameson Land, and one party undertook special geochronological investigations on Bjørneøer; the remaining 3 parties mapped in the Upper Palaeozoic and Mesozoic sediments of central and northern Jameson Land (see K. Perch-Nielsen, this report). Approximately $7000 \mathrm{~km}^{2}$ were mapped in the crystalline complexes, and about $2000 \mathrm{~km}^{2}$ in the Mesozoic sediments at a scale of 1:50 000. After two seasons mapping the field work between $71^{\circ} 15^{\prime}$ and $72^{\circ} 00 \mathrm{~N}$ is almost completed.

The crystalline complex

The area mapped in 1969 forms the direct eastwards continuation of the area mapped around inner Nordvestfjord during the 1968 season. The geological features encountered were in general somewhat different from those previously encountered, reflecting the fact that the 1969 field areas were located in the inner part of the Caledonian orogenic belt where migmatites and syn- and post-orogenic granites dominate.

The sequence of metamorphosed interbanded quartzitic and argillaceous rocks the upper part of the Krummedal supracrustal sequence - found around the inner part of Nordvestfjord (Henriksen \& Higgins, 1969) becomes intensely metamorphosed and migmatised towards the east and there are gradual transitions into the migmatitic gneisses and granites found around the central and outer parts of Nordvestfjord. The degree of migmatisation increases towards the east and results ultimately in the formation of synkinematic garnet-cordierite-biotite granites with small lensoid remnants of quartzitic beds. In the migmatitic regions remnants of the pre-migmatitic rocks are found in the form of bands and sometimes very thick sequences of almost completely pure quartzites, areas of banded rusty-brown garnet-biotite gneisses and marble horizons.

Sheets, up to $1000 \mathrm{~m}$ thick, of garnet-rich foliated augen granite form concordant 
and semiconcordant sheets in the migmatitic gneisses. The sheets are homogeneous and contain only few inclusions of the surrounding gneisses.

In the south-eastern part of the mapped area there occur a number of melanocratic biotite diorite intrusions. The main body occurs as a sheet up to $500 \mathrm{~m}$ thick which can be traced for more than $50 \mathrm{~km}$; a branch of this sheet can be shown to cut an augen gneiss sheet disconformably. The main extensive diorite sheet forms a basin structure, the interior of which is the locus of intense granitisation which resulted in the formation of an up to $1000 \mathrm{~m}$ thick sheet of foliated grey granite with horizontal or shallow dipping bands of lensoid gneiss inclusions. The biotite diorite bodies can be migmatised and metamorphosed, mainly along their margins, whereas the inner parts of the bodies have preserved their original magmatic textures.

The kyanite-garnet mica schists of the Krummedal sequence in the westernmost part of the fjord zone can be traced into sillimanite-garnet gneisses in the central part of the area, and further east finally into a zone of migmatites characterised by the occurrence of cordierite. This metamorphic sequence indicates an interesting westeast transition between a high pressure and a low pressure facies series.

The general structure of the region suggests that a first phase of deformation, which may have incorporated the augen granite sheets, developed a series of large recumbent folds sometimes with more than $5 \mathrm{~km}$ overlap. These major folds are considered to be mainly responsible for the flat-lying structures which dominate the region. A second phase of folding with vertical axial planes formed a number of open, N-S trending antiforms and synforms.

Postkinematic "granites" occur widely distributed in the region north of the outer part of Nordvestfjord. These granites form irregular sheet-like bodies or plugs up to $10-15 \mathrm{~km}$ across. The rocks have intrusive contact relations to the older surrounding migmatites. The composition of individual intrusive complexes is often very variable and includes both porphyritic and homogeneous fine-grained varieties with hornblende and/or biotite. Two-mica granites form fine-grained rock types. A hornblende syenitic rock type found in the interior of some of the granites is an interesting variety. Post-granitic aplites and muscovite pegmatites are the youngest acid intrusive rocks.

In south-western Liverpool Land a number of generally flat-lying gneiss series include banded garnet, biotite and/or hornblende gneisses, heterogeneous gneisses with basic inclusions, and granitic gneisses. Eclogitic rocks occur as lenses in garnetbearing gneisses assumed to form the lowest gneiss series. Marble bands have been observed at a few localities occurring as distinct horizons in the gneisses.

The gneisses are cut discordantly by a younger granite more than 30 by $12 \mathrm{~km}$ in extent - the Hurry Inlet granite. The granite is a leucocratic biotite granite containing rare pegmatites and veins. The marginal zone often contains abundant xenoliths of the country rock. A series of small hornblende diorite bodies probably forms a late member of the granite suite. Non-metamorphosed sediments rest on the Hurry Inlet granite along the north-east coast of Hurry Inlet where a few plant remains but no 
other fossils have been collected. The sedimentary sequence may represent strata of Upper Palaeozoic and Lower Mesozoic age.

\section{Tertiary basalts}

Mapping of the Tertiary basalts was carried out in the region south-west of Hall Bredning. In all 26 sections were traversed, distributed over the higher parts of Milne Land ( 15 sections), southern Gaaseland (one section) and the south coast of Scoresby Sund from Sydbræ to Borgvig (10 sections). The top of the basalt succession was reached on Milne Land and on some of the nunataks inland from Kap Stevenson.

On Milne Land the basalts overlie with a slight unconformity unfossiliferous yellow sandstones and a thin fossiliferous, buff-coloured sandstone containing ammonites and belemnites believed to be Upper Jurassic in age. Elsewhere the basalts overlie gneisses. Within the basalt succession on Milne Land there are a few thin, interbasaltic sandstones; silicified and charred wood was found associated with these.

The direction of magnetisation of the lava flows was determined using a hand compass. While the majority of flows show reverse magnetisation there are clearly zones of normal magnetisation. In the extreme south of the area these zones can be matched in different profiles and can here be used for correlation.

Correlation over longer distances is difficult because of the uniformity of the lava pile and lack of marker horizons. However, in the extreme south two distinct horizons within the basalt can be traced for many kilometres.

Pyroclastic deposits are common in the area around Kap Stevenson and Helgenæs where they weather to form terraces in the basalt succession. The area is possibly close to the site of a volcanic centre. Tall columnar piles within very thick flows are also common in this area.

\section{Quaternary}

Investigations of ice margin features and marine deposits on south-eastern Milne Land revealed the existence of terraces at 100-110, 70-80, 30-50 and 5-10 metres above present sea level. At the 100-110 m level moraine ridges and banks grade from a higher terrestial type into a lower presumably submarine type, and the maximum heights of many of the glaciofluviatile terraces and fans correspond to this level. It is therefore believed that the oldest and highest marine level is related to a major advance of the ice, which progressively retreated without any major younger advances. In all marine levels lower than 100-110 m shells have been found and collected for C-14 dating. Recent shells have also been collected for the same purpose.

Drill core samples were collected from a few post-glacial lake deposits on southwestern Jameson Land for pollen studies.

\section{Reference}

Henriksen, N. \& Higgins. A. K. 1969: Preliminary results of mapping in the crystalline complex around Nordvestfjord, Scoresby Sund, East Greenland. In Report on the 1968 geological expedition to Scoresby Sund, East Greenland. Rapp. Gronlands geol. Unders. 21, 5-20. 